\title{
Effect of a Matrix Metalloproteinase Activity and TNF-Alpha Converting Enzyme Inhibitor on Intra-Abdominal Adhesions ${ }^{1}$
}

\author{
U. Mirastschijski ${ }^{\mathrm{a}} \quad$ K. Johannesson ${ }^{\mathrm{a}} \quad$ B. Jeppsson ${ }^{\mathrm{a}} \quad$ M.S. Ågren ${ }^{\mathrm{b}}$ \\ ${ }^{a}$ Department of Experimental Surgery, Malmö University Hospital, Lund University, Malmö, Sweden; \\ ${ }^{b}$ Department of Surgery K, Bispebjerg Hospital, University of Copenhagen, Copenhagen, Denmark
}

\section{Key Words}

Hydroxamate inhibitor · GM 6001 - llomastat •

Galardin · Bromodeoxyuridine · Collagen · Peritoneum •

Wound healing

\begin{abstract}
Background: Formation of intra-abdominal adhesions depends, in part, on the activity of serine proteinases. Matrix metalloproteinases (MMP) are required for epithelialization of skin wounds but their involvement in mesothelialization of peritoneal wounds and in adhesion pathogenesis is not known. Early tumor necrosis factor$\alpha$ (TNF- $\alpha$ ) levels have been proposed to reflect propensity to adhesion formation. Objective: The impact of MMP activity and secreted TNF- $\alpha$ on peritoneal adhesion formation and healing was investigated through systemic administration of the synthetic broad-spectrum MMP and TNF- $\alpha$-converting enzyme (TACE) inhibitor GM 6001. Methods: Female Sprague-Dawley rats of 4-6 weeks of age were injected subcutaneously daily with GM 6001 $100 \mathrm{mg} / \mathrm{kg}(\mathrm{n}=12)$ or vehicle $(\mathrm{n}=10)$ starting two days before surgery. In each rat, two standardized peritoneal wounds, $20 \mathrm{~mm} \times 5 \mathrm{~mm}$, were made. One peritoneal wound was sutured whereas the contralateral wound
\end{abstract}

Presented in part at the Gordon Research Conference 'Tissue repair and regeneration', 17-22 June 2001, New London, N.H., USA. healed by secondary intention. Adhesion formation and peritoneal healing, cell proliferation, and hydroxyproline concentrations were evaluated on postoperative day 7. Results: Total serum TNF- $\alpha$ levels increased in vehicletreated rats ( $p=0.019$ ) while GM 6001 treatment effectively prevented the rise in the postoperative phase $(p<$ $0.001)$. No significant differences were observed in the extent of adhesion formation ( $p=0.67$ ) between control $(65.0 \%)$ and GM 6001-treated (61.5\%) animals, or peritoneal wound healing or cell proliferation. Hydroxyproline levels increased in the wounds $(p=0.014)$ but were not different between the two groups $(p=0.14)$. Conclusions: Lack of a striking effect of the MMP and TACE antagonist GM 6001 on postoperative adhesions suggests that MMP activity and TNF- $\alpha$ might not be major adhesiogenic factors.

Copyright (C) 2005 S. Karger AG, Basel

\section{Introduction}

Adhesion formation is a major complication in surgery $[1,2]$. It has been estimated that the annual health care costs associated with adhesiolysis procedures amount to more than USD 1 billion in the United States. The pathogenesis of adhesion formation is not entirely delineated; however, evidence suggests that fibrin, deposited early after peritoneal injury, bridges visceral organs with opposing surfaces resulting in adhesions. Subsequent fibro-

\section{KARGER \\ Fax +4161306 1234 E-Mail karger@karger.ch} www.karger.com (c) 2005 S. Karger AG, Basel 0014-312X/05/0371-0068\$22.00/0

Accessible online at: www.karger.com/esr
Magnus S. Ågren, MD

Department of Surgery K

Bispebjerg Hospital, Bispebjerg Bakke 23

DK-2400 Copenhagen NV (Denmark)

Tel. +45 3531 6493, Fax +45 4919 2825, E-Mail maa02@bbh.hosp.dk 
proliferative processes also contribute to the development of permanent adhesions. Contemporary reviews on this subject are published by Cheong et al. [3] and Chegini [4].

Exogenous plasminogen activators such as urokinase plasminogen activator ( $\mathrm{UPA}$ ) and tissue-type plasminogen activator (tPA) reduce adhesions whereas fibrinolytic inhibitors increase adhesions in experimental models (reviewed by Hellebrekers et al. [5]). Adhesions, induced by a laparoscopic procedure, were also more in uPA- and tPA-deficient mice and fewer in plaminogen inhibitor activatior-1 (PAI-1)-deficient mice [6]. Reduction of adhesions by pharmacological manipulation of the release of growth hormone and gonadotropin might be due to increased fibrinolytic activity $[7,8]$. In patients, a correlation has been observed between reduced postoperative endogenous tPA levels, increased PAI-1 tissue levels and the extent of adhesions formed [9]. Moreover, peritonitis is associated with increased adhesions and decreased tissue plasminogen activator activity [10].

As well as a role in fibrinolysis, the plasminogen system together with matrix metalloproteinases (MMP) are involved in tissue repair processes [11]. MMP are zinc-dependent endopeptidases comprising 23 human members mainly the collagenases, gelatinases, stromelysins and membrane-type MMP [12]. Collectively, MMP degrade all extracellular matrix (ECM) molecules. Results from recent clinical studies have been inconclusive regarding the participation of MMP in adhesions where tissues levels of selected MMP did not differ significantly between normal parietal peritoneum and adhesion tissue [13, 14]. On the other hand, the gelatinase B (MMP-9)/tissue inhibitor of metalloproteinases-1 (TIMP-1) ratio was elevated in peritoneal fluid from women with pelvic adhesions compared with women with normal pelvis at second-look laparoscopy [15]. This indicates that decreased MMP activity may reduce the propensity of adhesions to form.

Tumor necrosis factor- $\alpha(\mathrm{TNF}-\alpha)$ is a potent pro-inflammatory cytokine produced in response to abdominal injury. TNF- $\alpha$ levels were also increased in serum and peritoneal fluid in the immediate postoperative period and correlated to the extent of adhesions in rats [16]. TNF- $\alpha$ added to cultured mesothelial cells increased the levels of MMP-9 and reduced the levels of TIMP-1 [17].

Synthetic broad-spectrum MMP inhibitors of the hydroxamate class effectively block MMP activity and the disintegrin TNF- $\alpha$-converting enzyme (TACE) responsible for release of membrane-associated TNF- $\alpha$ [18]. These types of inhibitors also reduce the influx of inflam- matory cells following injury to mucous and serous membranes [19, 20]. Because MMP and TNF- $\alpha$ involvement in the development of adhesions and peritoneal wound healing is unclear we examined the systemic effect of the broad-acting MMP activity and TACE antagonist hydroxamate GM 6001 on adhesion formation and peritoneal wound healing in rats. Systemic GM 6001 treatment substantially increases biomechanical strength of left colon anastomoses in rats [21].

\section{Materials and Methods}

MMP and TACE Inhibitor GM 6001 (Ilomastat or Galardin)

GM 6001 (N-[(2R)-2-(hydroxamidocarbonylmethyl)-4-methylpentanoyl]- $L$-tryptophan-methylamide) was purchased from AMS Scientific (Concord, Calif., USA). The $\mathrm{IC}_{50}$ by GM 6001 of collagenase 1 (MMP-1) is $1.5 \mathrm{n} M$, of gelatinase A (MMP-2) $1.1 \mathrm{n} M$, of gelatinase B (MMP-9) $0.5 \mathrm{n} M$, of stromelysin 1 (MMP-3) $1.9 \mathrm{n} M$, and of membrane-type 1 MMP (MMP-14) $13.4 \mathrm{n} M$, according to Yamamoto et al. [22]. These levels are well below the steady-state plasma concentration of about $50 \mathrm{n} M 24 \mathrm{~h}$ after an intraperitoneal administration of $100 \mathrm{mg} / \mathrm{kg} \mathrm{GM} 6001$ [23].

\section{Animals and Treatment}

Twenty-two female Sprague-Dawley rats (M\&B, Ry, Denmark) of 4-6 weeks of age and weighing 95-140 g were housed under standard climatic conditions [24]. The animals had free access to pellets and tap water [24]. After a 5-day acclimatization period, animals were randomly allocated to treatment with GM 6001 or to treatment with the vehicle in a 6:5 ratio to compensate for the possibly higher mortality in the GM 6001 group. GM 6001, suspended homogenously in ethanol and PBS (phosphate-buffered saline) $(5 \mathrm{mg} / \mathrm{ml}$ ethanol/PBS), was administered to 12 rats once daily by subcutaneous injections at $100 \mathrm{mg} / \mathrm{kg}$ body weight at alternate sites. Systemic treatment with GM 6001 at this dosage effectively inhibits overall MMP activity by more than $85 \%$, as measured by the specific collagen degradation marker carboxy-terminal telopeptide of type I collagen in serum [21, 25]. Ten control-treated animals were injected subcutaneously with the same volumes of the vehicle alone. Treatment started two days prior to surgery and continued to postoperative day 6, i.e. each animal was injected 9 times. Animals from the two groups were mixed in Makrolon ${ }^{\circledR}$ cages and weighed daily before treatment.

Maximally $0.3 \mathrm{ml}$ of blood, representing less than $5 \%$ of the total circulating blood volume, was taken from tail veins two days before surgery, the day of operation just before surgery and 1, 3, 5 and 7 days after surgery. Hematological parameters return to baseline within $48 \mathrm{~h}$ when withdrawing these amounts of blood [26]. Serum was obtained after centrifugation and stored at $-80^{\circ} \mathrm{C}$ until analyzed for TNF- $\alpha$ levels.

The local Ethics Committee of Lund University (LU 234-00) approved the study.

\section{Wounding}

General anesthesia was induced by subcutaneous injection of a mixture of fentanyl citrate $(0.095 \mathrm{mg} / \mathrm{kg})$, fluanisone $(3 \mathrm{mg} / \mathrm{kg})$ and 
midazolam $(1.5 \mathrm{mg} / \mathrm{kg})$. The abdomen was shaved with electrical clippers and cleansed with $70 \%$ ethanol.

A standardized and validated model for inducing peritoneal adhesions in rodents was used as described by Holmdahl et al. [27]. The abdomen was opened by a 5-cm-long medial laparotomy. One 20-mm-long and 5-mm-wide peritoneal defect extending to the underlying musculature was made on each side of the linea alba using a scalpel blade. The incised peritoneal tissue was carefully removed with forceps. After stopping the minimal bleeding by mild compression, the defect on one side was closed with five interrupted 4-0 polyglycolic acid sutures (Dexon ${ }^{\circledR}$ II, DG Cyanamid of Great Britain, Gosport, UK) placed equidistantly $(5 \mathrm{~mm})$ with one stitch at the proximal and one stitch at the distal end of the wound $20 \mathrm{~mm}$ apart. The contralateral wound was left non-sutured, for assessment of mesothelialization. The right wound was sutured in half of the animals and the left wound sutured in the rest. Peritoneum and the linea alba were sutured with continuous 4-0 polyglycolic acid sutures and the skin with continuous 3-0 polyamide (Suturamid ${ }^{\circledR}$, Ethicon, Norderstedt, Germany).

\section{Evaluation of Adhesions and Peritoneal Wound Healing}

On postoperative day 7, 5-bromo-2'-deoxyuridine (BrdU, Sigma-Aldrich, St. Louis, Mo., USA) was injected intramuscularly at $50 \mathrm{mg} / \mathrm{kg} 1 \mathrm{~h}$ before the rats were killed. Rats were then anesthetized, the abdomen opened widely and adhesions assessed. The length of adhesions attached to the sutured wound and original peritoneal defect, defined by the distance between the end stitches, was measured with a slide-caliper in $\mathrm{mm}$ as described in detail by Holmdahl et al. [27]. The proportion of the peritoneal defect covered by the sum of individual adhesion attachments was calculated and expressed as percentage (\%) of the original defect [27]. The degree of adhesion remains maximal from postoperative day 7 to day 21 in this adhesion model [27]. Presumably the quality of the adhesions changed beyond day 7 due to remodeling by local and general fibrinolytic processes as well as by MMP. Healing of the non-sutured peritoneal wound was judged as healed or non-healed by visual inspection.

Tissue Sampling for Hydroxyproline Analyses and Histology

Adhesions were removed and tissue samples excised between the sutures from the sutured wounds and from the middle of the non-sutured wounds using a 3-mm trephine. Adjacent non-wounded peritoneum was also sampled with a $3-\mathrm{mm}$ trephine. Samples, fresh weight about $5 \mathrm{mg}$, were stored at $-20^{\circ} \mathrm{C}$ until analyzed for hydroxyproline.

Animals were killed by carbon dioxide asphyxiation or by perfusion with PBS-buffered 10\% formalin. Adhesions and peritoneal wounds were excised and embedded in paraffin. 4- $\mu \mathrm{m}$ sections were cut and placed on Superfrost ${ }^{\circledR}$ Plus microscopic slides, the sections deparaffinized in xylene and rehydrated.

\section{Histological and Proliferation Assessments}

Morphology of adhesions and peritoneal wounds were evaluated in hematoxylin-eosin-stained sections using light microscopy.

The proliferation marker BrdU was immunodetected using a mouse monoclonal antibody against BrdU (M744; Dako, Glostrup, Denmark) and a visualization system with Fast red as the chromogen [28]. Control sections treated identically but without the primary antibody did not demonstrate any positive staining (data not shown). In non-sutured peritoneal wounds, two consecutive highpower fields of view (each $0.159 \mathrm{~mm}^{2}$ ) in the middle of the wounds from the mesothelium downwards $(0.45 \mathrm{~mm})$ were examined and BrdU-immunopositive cells quantified by light microscopy.

\section{Hydroxyproline Measurements}

Tissues were dried to constant weight at $100^{\circ} \mathrm{C}$ and were hydrolyzed in $6 \mathrm{M} \mathrm{HCl}$ for $18 \mathrm{~h}$ at $110^{\circ} \mathrm{C}$ in tightly capped borosilicate Pyrex $^{\circledR}$ tubes (No. 9826-16; Corning ${ }^{\circledR}$, Corning, N.Y., USA). The acid hydrolysates were transferred to borosilicate Pyrex ${ }^{\circledR}$ beakers and evaporated on a hot plate at $100^{\circ} \mathrm{C}$. The residues were washed three times with $10 \mathrm{ml}$ deionized water with complete evaporation between each wash step to remove residual acid. Complimentary experiments demonstrated a complete recovery of added known amounts of hydroxyproline using this method. The acid-free samples were reconstituted in $2.0 \mathrm{ml}$ of acetate-citrate buffer $(0.88 \mathrm{M}$ sodium acetate trihydrate, $0.24 \mathrm{M}$ citric acid, $0.21 \mathrm{M}$ acetic acid and $0.85 \mathrm{M}$ sodium hydroxide, $\mathrm{pH}$ 6.0) and sonicated for $20 \mathrm{~min}$. 4-hydroxy- $L$-proline (H1637; Sigma-Aldrich) standard (0-1.25 $\mu \mathrm{g} /$ $\mathrm{ml}$ ), samples and blanks were run simultaneously. $200 \mu \mathrm{l}$ of $0.06 \mathrm{M}$ chloramine-T in 50\% (v/v) 1-propanol was added to $400 \mu 1$ of sample, standard and blank. After 20 min of incubation at room temperature, $200 \mu \mathrm{l}$ of $1 \mathrm{Mp}$-dimethylaminobenzaldehyde in $3.7 \mathrm{M}$ perchloric acid and $60 \%$ (v/v) 1-propanol were added. Samples were incubated at $60^{\circ} \mathrm{C}$ for $15 \mathrm{~min}$ and then cooled in an ice-water bath. Duplicate $300-\mu 1$ aliquots of each sample were transferred to a microtiter plate and absorbances read at $550 \mathrm{~nm}$. Hydroxyproline concentrations of the unknowns were calculated from the linear standard curve and are presented as $\mu \mathrm{g} / \mathrm{mg}$ dry tissue weight.

\section{TNF- $\alpha$ Serum Levels}

The concentration of total and free TNF- $\alpha$ in sera was measured using the sandwich enzyme-linked immunosorbent assays OptEIA (PharMingen, San Diego, Calif., USA) and CytElisa (Cytimmune, College Park, Md., USA), respectively.

According to the manufacturers, the lowest level of detection of the OptEIA assay is $13 \mathrm{pg} / \mathrm{ml}$ and for the CytElisa $15.6 \mathrm{pg} / \mathrm{ml}$. A $50-\mu 1$ aliquot of serum was mixed with $50 \mu \mathrm{l}$ of assay diluent and the assays run according to the manufacturers' instructions together with a recombinant rat TNF- $\alpha$ standard. Recovery of TNF- $\alpha$ was examined by adding a known amount of standard $(125 \mathrm{pg} / \mathrm{ml})$ to sera from control and GM 6001-treated animals obtained 1 day after surgery.

\section{Blinding}

The same surgeon, unaware of the treatment given, performed the surgery, evaluation of adhesions and peritoneal wound healing and histological assessments. TNF- $\alpha$ and hydroxyproline determinations were carried out without prior knowledge of group affiliation.

\section{Statistical Analyses}

Mann-Whitney test was used to determine the significance of differences in body weight gain, extent of adhesions and cell proliferation (BrdU) between control and GM 6001-treated groups. TNF- $\alpha$ (repeated measurements) and hydroxyproline levels were analyzed by analyses of variance (ANOVA). In the case of statistical significance, Bonferrroni's post-hoc test was used to determine which values differed. $\mathrm{p}<0.05$ was chosen as the level of statistical significance. Data are given as median (interquartile range). 
Table 1. Total TNF- $\alpha$ levels $(\mathrm{pg} / \mathrm{ml})$ in rat serum in controls and in GM 6001-treated animals

\begin{tabular}{|c|c|c|c|c|c|c|}
\hline \multirow[t]{2}{*}{ Treatment } & \multicolumn{6}{|l|}{ Day } \\
\hline & -2 & 0 & 1 & 3 & 5 & 7 \\
\hline \multicolumn{7}{|l|}{ Control } \\
\hline Median & 148 & 152 & 157 & 178 & 185 & 176 \\
\hline Interquartile range & $148-150$ & $141-155$ & $146-159$ & $168-182$ & $173-189$ & $166-184$ \\
\hline $\mathrm{n}$ & 5 & 5 & 5 & 4 & 4 & 5 \\
\hline \multicolumn{7}{|l|}{ GM 6001} \\
\hline Median & 155 & 146 & 152 & $151^{*}$ & $152 *$ & 157 \\
\hline Interquartile range & $143-157$ & $145-152$ & $147-158$ & $149-158$ & $147-156$ & $151-165$ \\
\hline $\mathrm{n}$ & 6 & 6 & 8 & 7 & 9 & 9 \\
\hline
\end{tabular}

Day $-2=$ Start of the experiment; day $0=$ day of operation before surgery; day $7=$ end of experiment.

$\mathrm{n}=$ Number of rats.

$* \mathrm{p}<0.05$ vs. control.

\section{Results}

Treatment with the MMP and TACE inhibitor GM 6001 caused no visible general untoward effects. GM 6001-treated rats gained weight at a slightly slower rate than control rats given vehicle only although the median gain of body weight from 2 days before surgery to day 7 after surgery did not differ significantly $(\mathrm{p}=0.10)$ between GM 6001 (26.0\% (interquartile range, 18.7$32.0 \%)$ ) and control $(35.2 \%(24.6-41.2 \%))$ groups. One rat in the control group died just after surgery most likely due to the anesthesia.

\section{TNF- $\alpha$ Serum Levels}

In controls, total TNF- $\alpha$ levels increased significantly $(p=0.019)$ after injury and were significantly $(p<0.001)$ different from those of the GM 6001-treated rats (table 1). Free TNF- $\alpha$ could not be detected in any of the serum samples obtained either pre- or postoperatively. Addition of recombinant rat TNF- $\alpha$ to the rat serum was recovered when assessing total TNF- $\alpha$ but not when free TNF- $\alpha$ was measured, suggesting the presence of excessive soluble TNF- $\alpha$ receptors in the serum samples.

\section{Adhesions and Peritoneal Wound Healing}

Adhesions were found predominately between the sutured peritoneal wound and omentum or liver postoperative day 7 (table 2). No apparent differences in the number or sites of adhesions were seen between control and GM 6001-treated rats (table 2). The length of the control sutured wounds $(\mathrm{n}=9)$ was $20.0 \mathrm{~mm}(20.0-22.0 \mathrm{~mm})$ and
Table 2. Occurrence of adhesions between the peritoneal wound site and different organs on postoperative day 7

\begin{tabular}{|c|c|c|c|c|}
\hline \multirow[t]{2}{*}{ Organ } & \multicolumn{2}{|c|}{ Non-sutured site } & \multicolumn{2}{|c|}{ Sutured site } \\
\hline & $\begin{array}{l}\text { control } \\
(\mathrm{n}=9)\end{array}$ & $\begin{array}{l}\text { GM } 6001 \\
(\mathrm{n}=12)\end{array}$ & $\begin{array}{l}\text { control } \\
(\mathrm{n}=9)\end{array}$ & $\begin{array}{l}\text { GM 6001 } \\
(\mathrm{n}=12)\end{array}$ \\
\hline Omentum & 1 & 2 & 4 & 7 \\
\hline Liver & 3 & 1 & 7 & 7 \\
\hline Spleen & 0 & 0 & 1 & 1 \\
\hline
\end{tabular}

$\mathrm{n}=$ Number of rats.

of the GM 6001 sutured wounds $(\mathrm{n}=12) 19.5 \mathrm{~mm}(17.8$ $20.0 \mathrm{~mm}$ ). The percentage area of the sutured wound covered by adhesions was $65.0 \%(27.0-100.0 \%)$ in the control group $(\mathrm{n}=9)$ and $61.5 \%(28.8-86.5 \%)$ in the GM 6001 group $(n=12)$, a statistically non-significant difference $(p=0.67)$. Microscopically, granulation tissue had formed in the contact zone between the wounds and internal organs in the two groups (fig. 1).

Rarely organs adhered to the non-sutured peritoneal wounds (table 2) or to the sutured midline laparotomy wounds. The non-sutured peritoneal wounds were completely mesothelialized by day 7 in both groups. The wounds were easily identified by the opaque glistening of the scar. Microscopically, granulation tissue was observed underneath a single-layered mesothelium in both groups. A conspicuous morphological difference was the round cells in the granulation tissue in GM 6001-treated ani- 


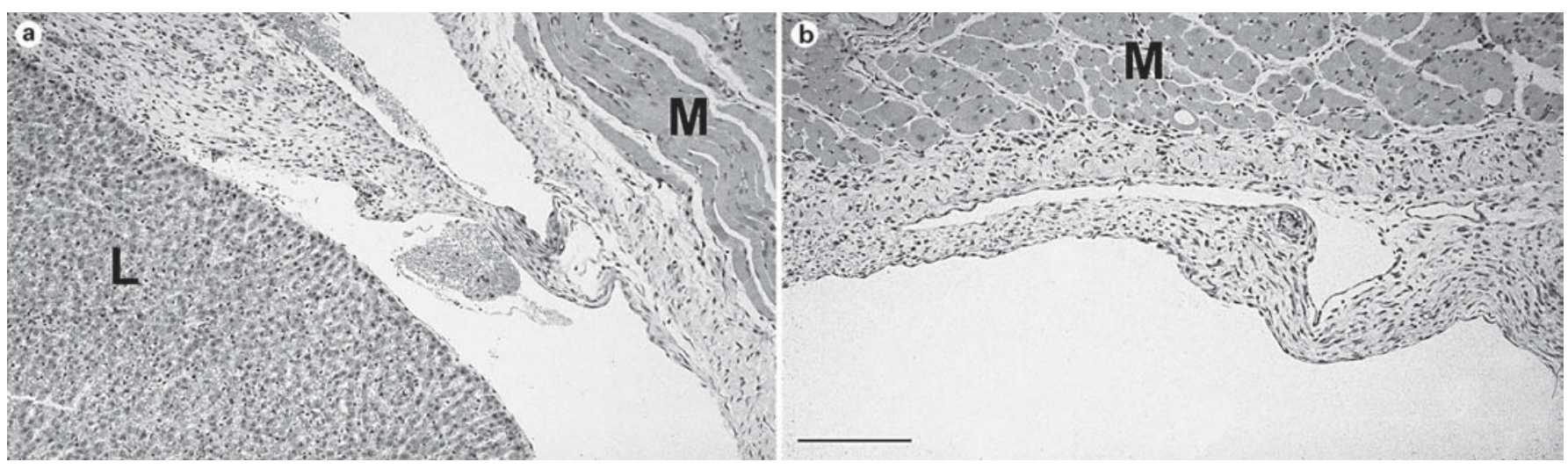

Fig. 1. Morphology of adhesions to sutured peritoneal wounds in rats treated without (a) or with GM 6001 (b) on postoperative day 7. a Adhesion between peritoneum with underlying musculature (M) and liver (L) in control. b Granulation tissue in peritoneal wound adjacent to suture in the GM 6001 group. HE. Scale bar in $\mathbf{b}=$ $200 \mu \mathrm{m}$.

Fig. 2. BrdU labeling of open, non-sutured peritoneal wounds in control (a) and GM 6001-treated rats (b) postoperative day 7 . a DNA-synthesizing cells (labeled nuclei) in a single layer of mesothelium over granulation tissue in control. b Corresponding area in a GM 6001-treated rat. Also note the spindle-shaped cells in controls and round cells in granulation tissue of GM 6001treated animals. Scale bar in $\mathbf{b}=25 \mu \mathrm{m}$.

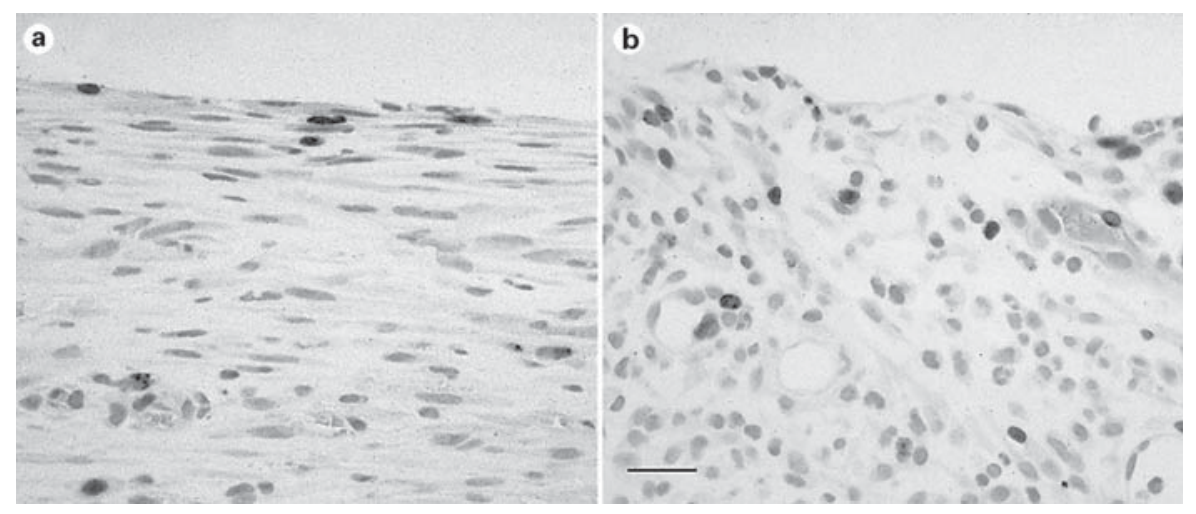

mals (fig. 2b) while the cells were spindle-shaped in controls (fig. 2a). Cell proliferation was studied after a 1-hour pulse with the thymidine analogue BrdU. The total proliferative activity of mesothelium and underlying granulation tissue did not differ significantly $(\mathrm{p}=0.32)$ between the control (56.6 (27.5-76.3) BrdU-positive cells $/ \mathrm{mm}^{2}$, $\mathrm{n}=8)$ and the GM 6001 group (78.6 (39.3-136.8) BrdUpositive cells $/ \mathrm{mm}^{2}, \mathrm{n}=11$ ).

Hydroxyproline levels were measured biochemically as an indicator of collagen. The fibrotic reactions seen histologically in the peritoneal wounds were reflected in elevated ( $p=0.014$, ANOVA) hydroxyproline levels compared with adjacent normal peritoneum (fig. 3). No significant $(p=0.14)$ differences in hydroxyproline concentrations in either uninjured or injured peritoneum were found between control and GM 6001-treated animals (fig. 3).

\section{Discussion}

The role of MMP activity on the formation of postoperative intra-abdominal adhesions in young rats was examined using the broad-spectrum MMP inhibitor GM 6001. This compound was found beneficial for colon anastomosis healing in another study [21]. GM $6001 \mathrm{did}$ not significantly influence the degree of adhesion formation suggesting that MMP activity does not play a major role in adhesion pathogenesis in the experimental model used in this study [27]. This finding further suggests that anti-adhesion therapies should possibly be targeted against proteolytic enzyme systems other than MMP. However, we cannot extrapolate our results to adults or rule out a role of MMP in remodeling of already established adhesions.

Mesothelial repair of injured peritoneum is likely to be achieved by different concurrent processes. Mesothe- 


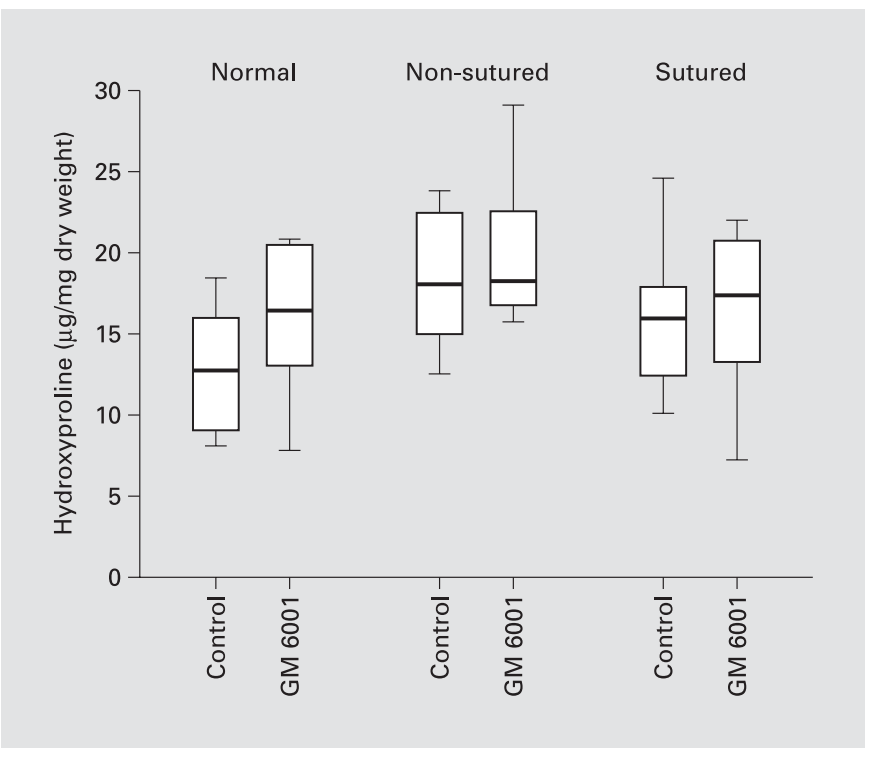

Fig. 3. Hydroxyproline concentration in adjacent normal peritoneum ( $\mathrm{n}=8$ and $\mathrm{n}=8)$, non-sutured peritoneal wounds $(\mathrm{n}=8$ and $\mathrm{n}=7$ ) and sutured peritoneal wounds $\mathrm{n}=8$ and $\mathrm{n}=8$ ) in the control and GM 6001 groups on postoperative day 7. Hydroxyproline levels were significantly ( $\mathrm{p}=0.018$, Bonferroni's post-hoc) elevated by $41 \%$ in non-sutured wounds compared to adjacent normal peritoneum in controls. There were no significant differences between control and GM 6001-treated animals. Box represents 25 th to 75 th percentile range (interquartile range), whiskers 5 th to 95 th percentile range and the horizontal line within the box indicates the median value. $n=$ Number of rats analyzed. Samples were lost from 1 control and 4 GM 6001 rats due to technical errors.

lial cells adjacent to and apposing the wound proliferate giving rise to two populations of cells, those that migrate across the wound surface and those that detach from their substratum, float in the serosal fluid and settle on the injured surface [29]. Also, it has been proposed that mesothelial cells, possibly originating from undifferentiated mesenchymal cells, move from the underlying connective tissue to the wound surface [30], although this theory has been disputed by Mutsaers and colleagues [29, 31]. Both processes explain the observation that peritoneal wounds heal at the same rate irrespectively of size $[32,33]$. Whatever the exact mechanism of mesothelial wound healing, these processes appear not to be MMP activity dependent. We cannot exclude the possibility that the GM 6001 actually enhanced peritoneal healing although this seems unlikely due to the similar degree of peritoneal adhesions in the two groups.

In other studies, treatment with the synthetic MMP inhibitor GM 6001, at the dosage used in the present study, increased the biomechanical strength of incisional skin wounds but profoundly impaired keratinocyte migration $[11,34]$. The difference in peritoneal wound mesothelialization and skin wound epithelialization, with respect to response to MMP activity inhibition, is intriguing. The mesothelial cell is mesenchymally derived whereas the epidermal keratinocyte originates from the ectoderm, possibly reflecting fundamental cellular differences in interactions with ECM [35]. Wolf et al. [36] reported unimpaired migration of mesenchymal cells despite inactivation of MMP in three-dimensional in vitro and in vivo collagen environments.

Although cell proliferation in the wounds was similar in the two groups, the cells in GM 6001-treated rats showed an aberrant, round phenotype compared to the control cells that showed typical morphological features of bipolar fibroblastic cells or contractile myofibroblasts. Analogously, migrating mesenchymal cells adopted an amoeboid morphology as a result of MMP inhibition in a three-dimensional collagen matrix [36]. Furthermore, Wong et al. [37] noted that GM 6001 treatment reduced the number of myofibroblasts in scarred rabbit eye. The phenotypic alteration of stromal cells by GM $6001 \mathrm{did}$ not appear to influence the healing response in peritoneum possibly because contraction contributes minimally to the healing of peritoneal wounds [27]. Myofibroblasts are common in mature human peritoneal adhesions and may contribute to some of the clinical symptoms [38]. Evidently the long-term effects of GM 6001 treatment on cell differentiation and clinical consequences need to be studied further.

Being a broad-spectrum hydroxamate MMP inhibitor GM 6001 presumably attenuated the catalytic activity of MMP. In our study, collagen concentration was elevated in the peritoneal wounds but was similar in the control and GM 6001 groups. Collagen accumulation is the net result of collagen synthesis and degradation. It is possible then that decreased collagen degradation through MMP inhibition was compensated for by decreased collagen synthesis in the GM 6001 group. In support of this hypothesis, Witte et al. [34] reported that GM 6001 treatment $(100 \mathrm{mg} / \mathrm{kg})$ reduced type I collagen mRNA levels in subcutaneous granulomas in rats.

GM 6001, like other broad-spectrum hydroxamate MMP inhibitors, also prevents the rise of serum TNF- $\alpha$ levels in conjunction with sepsis and chemotherapy [39, 40]. We measured both total and unbound TNF- $\alpha$ levels in serum as a representative way of examining the sum of bound and unbound TNF- $\alpha$ and bioactive TNF- $\alpha$, respectively. Total TNF- $\alpha$ levels increased postoperatively 
in controls as a result of inflammatory processes initiated by the surgical trauma. With GM 6001 treatment, total TNF- $\alpha$ levels did not, as anticipated, increase postoperatively. However, no unbound TNF- $\alpha$ was detected, possibly because soluble TNF- $\alpha$ receptors may have bound any free TNF- $\alpha$. Regardless, soluble TNF- $\alpha$ alone does not appear to play a major role in the development of adhesions. In a septic peritonitis murine model, Echtenacher at al. [41] speculated that reduced adhesions with an anti-TNF- $\alpha$ monoclonal antibody were attributed to the procoagulant effect of TNF- $\alpha$. Remarkably, reduction of peritoneal adhesions was accompanied with increased mortality possibly by the spreading of intestinal bacteria normally sequestered by the adhesions [41].
In summary, based on our findings the incidence of postoperative intra-abdominal adhesions does not decrease with short-term MMP and TACE inhibitor treatment suggesting that neither MMP activity nor TNF- $\alpha$ significantly induce the formation of adhesions.

\section{Acknowledgments}

Dr. Lena Holmdahl and Marina Halvarsson are acknowledged for introducing the adhesion model. Dr. Lars Nannestad Jørgensen assisted with statistical analyses and figure drawings. Dr. Steve Mutsaers reviewed the manuscript. We thank Dr. Lennart Bondeson, Dr. Diya Adawi, Elise Nilsson for their help. Financial support was given by the Medical Research Council, Einar and Inga Nilsson's Foundation, and Malmö University Hospital.

\section{References}

1 Holmdahl L: Making and covering of surgical footprints. Lancet 1999;353:1456-1457.

2 Parker MC, Ellis H, Moran BJ, Thompson JN, Wilson MS, Menzies D, McGuire A, Lower AM, Hawthorn RJ, O’Briena F, Buchan S, Crowe AM: Postoperative adhesions: Ten-year follow-up of 12,584 patients undergoing lower abdominal surgery. Dis Colon Rectum 2001; 44:822-830.

-3 Cheong YC, Laird SM, Li TC, Shelton JB, Ledger WL, Cooke ID: Peritoneal healing and adhesion formation/reformation. Hum Reprod Update 2001;7:556-566.

4 Chegini N: Peritoneal molecular environment, adhesion formation and clinical implication. Front Biosci 2002;7:e91-e115.

5 Hellebrekers BW, Trimbos-Kemper TC, Trimbos JB, Emeis JJ, Kooistra T: Use of fibrinolytic agents in the prevention of postoperative adhesion formation. Fertil Steril 2000;74:203212.

-6 Molinas CR, Elkelani O, Campo R, Luttun A, Carmeliet P, Koninckx PR: Role of the plasminogen system in basal adhesion formation and carbon dioxide pneumoperitoneum-enhanced adhesion formation after laparoscopic surgery in transgenic mice. Fertil Steril 2003; 80:184-192.

7 Lai HS, Chen Y, Chang KJ, Chen WJ: Effects of octreotide on epidermal growth factor receptor, tissue plasminogen activator, and plasminogen activator inhibitor during intraperitoneal adhesion formation. J Gastroenterol 2003;38: $555-560$.

-8 Imai A, Sugiyama M, Furui T, Takahashi S, Tamaya T: Gonadotrophin-releasing hormones agonist therapy increases peritoneal fibrinolytic activity and prevents adhesion formation after myomectomy. J Obstet Gynaecol 2003;23:660-663.
-9 Ivarsson ML, Bergström M, Eriksson E, Risberg B, Holmdahl L: Tissue markers as predictors of postoperative adhesions. Br J Surg 1998;85:1549-1554.

10 Ince A, Eroglu A, Tarhan O, Bulbul M: Peritoneal fibrinolytic activity in peritonitis. Am J Surg 2002;183:67-69.

11 Lund LR, Rømer J, Bugge TH, Nielsen BS, Frandsen TL, Degen JL, Stephens RW, Danø K: Functional overlap between two classes of matrix-degrading proteases in wound healing. EMBO J 1999; 18:4645-4656.

12 Stamenkovic I: Extracellular matrix remodelling: The role of matrix metalloproteinases. $\mathrm{J}$ Pathol 2003;200:448-464.

13 Chegini N, Kotseos K, Zhao Y, Ma C, McLean F, Diamond MP, Holmdahl L, Burns J: Expression of matrix metalloproteinase (MMP-1) and tissue inhibitor of MMP in serosal tissue of intraperitoneal organs and adhesions. Fertil Steril 2001;76:1212-1219.

14 Chegini N, Zhao Y, Kotseos K, Ma C, Bennett B, Diamond MP, Holmdahl L, Skinner K: Differential expression of matrix metalloproteinase and tissue inhibitor of MMP in serosal tissue of intraperitoneal organs and adhesions. BJOG 2002;109:1041-1049.

15 Cheong YC, Shelton JB, Laird SM, Li TC, Ledger WL, Cooke ID: Peritoneal fluid concentrations of matrix metalloproteinase- 9 , tissue inhibitor of metalloproteinase-1, and transforming growth factor-beta in women with pelvic adhesions. Fertil Steril 2003;79:11681175.

16 Kaidi AA, Gurchumelidze T, Nazzal M, Figert P, Vanterpool C, Silva Y: Tumor necrosis factor-alpha: A marker for peritoneal adhesion formation. J Surg Res 1995;58:516-518.
17 Zhu Z, Yao J, Wang F, Xu Q: TNF-alpha and the phenotypic transformation of human peritoneal mesothelial cell. Chin Med J (Engl) 2002;115:513-517.

18 Black RA, Rauch CT, Kozlosky CJ, Peschon JJ, Slack JL, Wolfson MF, Castner BJ, Stocking KL, Reddy P, Srinivasan S, Nelson N, Boiani N, Schooley KA, Gerhart M, Davis R, Fitzner JN, Johnson RS, Paxton RJ, March CJ, Cerretti DP: A metalloproteinase disintegrin that releases tumour-necrosis factor-alpha from cells. Nature 1997;385:729-733.

19 Trifilieff A, Walker C, Keller T, Kottirsch G, Neumann U: Pharmacological profile of PKF242-484 and PKF241-466, novel dual inhibitors of TNF-alpha converting enzyme and matrix metalloproteinases, in models of airway inflammation. $\mathrm{Br} \mathrm{J}$ Pharmacol 2002;135: 1655-1664.

20 Galardy RE, Cassabonne ME, Giese C, Gilbert JH, Lapierre F, Lopez H, Schaefer ME, Stack R, Sullivan M, Summers B, Tressler R, Tyrrell $\mathrm{D}$, Wee J, Allen SD, Castellot JJ, Barletta JP, Schultz GS, Fernandez LA, Fisher S, Cui TY, Foellmer HG, Grobelny D, Holleran WM: Low molecular weight inhibitors in corneal ulceration. Ann N Y Acad Sci 1994;732:315323.

21 Ågren MS, Jorgensen LN, Delaissé JM: Matrix metalloproteinases and colon anastomosis repair: A new indication for pharmacological inhibition? Mini Rev Med Chem 2004;4:769778.

22 Yamamoto M, Tsujishita H, Hori N, Ohishi Y, Inoue $\mathrm{S}$, Ikeda $\mathrm{S}$, Okada $\mathrm{Y}$ : Inhibition of membrane-type 1 matrix metalloproteinase by hydroxamate inhibitors: An examination of the subsite pocket. J Med Chem 1998;41:12091217. 
23 Bendeck MP, Irvin C, Reidy MA: Inhibition of matrix metalloproteinase activity inhibits smooth muscle cell migration but not neointimal thickening after arterial injury. Circ Res 1996;78:38-43.

-24 Syk I, Ågren MS, Adawi D, Jeppsson B: Inhibition of matrix metalloproteinases enhances breaking strength of colonic anastomoses in an experimental model. Br J Surg 2001;88:228234.

\25 Garnero P, Ferreras M, Karsdal MA, Nicamhlaoibh R, Risteli J, Borel O, Qvist P, Delmas PD, Foged NT, Delaissé JM: The type I collagen fragments ICTP and CTX reveal distinct enzymatic pathways of bone collagen degradation. J Bone Miner Res 2003;18:859-867.

-26 Nahas K, Provost JP, Baneux PH, Rabemampianina Y: Effects of acute blood removal via the sublingual vein on haematological and clinical parameters in Sprague-Dawley rats. Lab Anim 2000;34:362-371.

-27 Holmdahl L, Al-Jabreen M, Risberg B: Experimental models for quantitative studies on adhesion formation in rats and rabbits. Eur Surg Res 1994;26:248-256.

-28 Mirastschijski U, Impola U, Karsdal MA, Saarialho-Kere U, Ågren MS: Matrix metalloproteinase inhibitor BB-3103 unlike the serine proteinase inhibitor aprotinin abrogates epidermal healing of human skin wounds ex vivo. J Invest Dermatol 2002;118:55-64.
29 Foley-Comer AJ, Herrick SE, Al-Mishlab T, Prele CM, Laurent GJ, Mutsaers SE: Evidence for incorporation of free-floating mesothelial cells as a mechanism of serosal healing. J Cell Sci 2002; 115:1383-1389.

30 Bittinger F, Schepp C, Brochhausen C, Lehr HA, Otto M, Köhler H, Skarke C, Walgenbach S, Kirkpatrick CJ: Remodeling of peritoneallike structures by mesothelial cells: Its role in peritoneal healing. J Surg Res 1999;82:2833.

31 Mutsaers SE, Whitaker D, Papadimitriou JM: Mesothelial regeneration is not dependent on subserosal cells. J Pathol 2000;190:86-92.

32 Ellis H, Harrison W, Hugh TB: The Healing of peritoneum under normal and pathological conditions. Br J Surg 1965;52:471-476.

33 Raftery AT: Regeneration of parietal and visceral peritoneum: A light microscopic study. Br J Surg 1973;60:293-299.

34 Witte MB, Thornton FJ, Kiyama T, Efron DT, Schulz GS, Moldawer LL, Barbul A: Metalloproteinase inhibitors and wound healing: A novel enhancer of wound strength. Surgery 1998;124:464-470.

35 Mutsaers SE: The mesothelial cell. Int J Biochem Cell Biol 2004;36:9-16.
36 Wolf K, Mazo I, Leung H, Engelke K, von Andrian UH, Deryugina EI, Strongin AY, Bröcker EB, Friedl P: Compensation mechanism in tumor cell migration: Mesenchymal-amoeboid transition after blocking of pericellular proteolysis. J Cell Biol 2003;160:267-277.

37 Wong TT, Mead AL, Khaw PT: Matrix metalloproteinase inhibition modulates postoperative scarring after experimental glaucoma filtration surgery. Invest Ophthalmol Vis Sci 2003;44:1097-1103.

38 Xu X, Rivkind A, Pappo O, Pikarsky A, LeviSchaffer F: Role of mast cells and myofibroblasts in human peritoneal adhesion formation. Ann Surg 2002;236:593-601.

39 Mazolewski PJ, Barber A, Williams S, Simoni J, Davis S, Shires GT: Attenuating tumor necrosis factor-alpha does not ameliorate other cytokine and peroxidase products during sepsis. Am J Surg 1999; 178:556-559.

40 Ramesh G, Reeves WB: TNF-alpha mediates chemokine and cytokine expression and renal injury in cisplatin nephrotoxicity. J Clin Invest 2002; 110:835-842.

41 Echtenacher B, Weigl K, Lehn N, Männel DN: Tumor necrosis factor-dependent adhesions as a major protective mechanism early in septic peritonitis in mice. Infect Immun 2001;69: 3550-3555. 